\title{
Article \\ Modes of Occurrence of Chromium and Their Thermal Stability in Low-Rank Coal Pyrolysis
}

\author{
Xiaobing Wang ${ }^{1,+}\left(\mathbb{D}\right.$, Lingmei Zhou ${ }^{1, *,+}$, Shuquan Zhu ${ }^{1}$, Hao Zheng ${ }^{1}$, Yue Ma ${ }^{1}$, Yuchen Liu ${ }^{1}$, Chenxin Jia ${ }^{1}$, \\ Changjiang Zhou ${ }^{1}$, Lijuan Bie ${ }^{1}$ and Guanjun Zhang ${ }^{2}$ \\ 1 School of Chemical and Environmental Engineering, China University of Mining and Technology-Beijing, \\ Beijing 100083, China; wangxb1219@163.com (X.W.); zsq@cumtb.edu.cn (S.Z.); \\ zhenghao001001@163.com (H.Z.); mayao7151@foxmail.com (Y.M.); 1992079043@163.com (Y.L.); \\ j15203907552@163.com (C.J.); zcj18811768221@163.com (C.Z.); bielijuan1998@163.com (L.B.) \\ 2 Beijing Smart-Chip Microelectronics Technology Co., Ltd., Beijing 100192, China; \\ zhangguanjun@sgitg.sgcc.com.cn \\ * Correspondence: 201506@cumtb.edu.cn; Tel.: +86-10-6233-9616 \\ + These authors contributed equally to this work and should be considered co-first authors.
}

check for updates

Citation: Wang, X.; Zhou, L.; Zhu, S.; Zheng, H.; Ma, Y.; Liu, Y.; Jia, C.;

Zhou, C.; Bie, L.; Zhang, G. Modes of Occurrence of Chromium and Their Thermal Stability in Low-Rank Coal Pyrolysis. Processes 2022, 10, 15. https://doi.org/10.3390/pr10010015

Academic Editor: Adam Smoliński

Received: 19 November 2021

Accepted: 22 December 2021

Published: 23 December 2021

Publisher's Note: MDPI stays neutral with regard to jurisdictional claims in published maps and institutional affiliations.

Copyright: (C) 2021 by the authors. Licensee MDPI, Basel, Switzerland. This article is an open access article distributed under the terms and conditions of the Creative Commons Attribution (CC BY) license (https:// creativecommons.org/licenses/by/ $4.0 /)$.

\begin{abstract}
Chromium ( $\mathrm{Cr}$ ) and the emission of its compounds into the environment have caused long-term environmental contamination. In this study, the modes of occurrence of $\mathrm{Cr}$ in low-rank coal and their thermal stability in pyrolysis were investigated by sequential chemical extraction (SCE), single-component samples (SCS) pyrolysis, and thermochemical equilibrium simulation. The results showed that organic matter, aluminosilicate, and carbonate were the dominant modes of occurrence of $\mathrm{Cr}$ in low-rank coal. The modes of occurrence and chlorine $(\mathrm{Cl})$ content affected the volatilization of $\mathrm{Cr}$ in coal. The characteristic release temperature range of $\mathrm{Cr}$ bounded to aluminosilicate was $>600{ }^{\circ} \mathrm{C}$ and $400-600{ }^{\circ} \mathrm{C}$ for $\mathrm{Cr}$ bounded to a disulfide. Cr bounded to organic matter almost released completely before $600{ }^{\circ} \mathrm{C}$. $\mathrm{Cl}$ enhanced the volatility of $\mathrm{Cr}$ and reduced its release temperature in $\mathrm{Cr}$ bounded to aluminosilicate. The simulation showed the content of gas products was very low, mainly chlorides. While the content of solid products, sulfides, and oxides, was much higher than gas products, showing their high thermal stability. The sulfides and oxides in chars were closely related to the carbonate and aluminosilicate bound form of $\mathrm{Cr}$. The results of the equilibrium simulation were consistent with the experimental results.
\end{abstract}

Keywords: toxic trace elements; low-rank coal; modes of occurrence; single-component samples pyrolysis; release behavior; thermochemical equilibrium simulation

\section{Introduction}

Coal was one of the most important energies in the world, especially in China. It played an important role in the development of social and economic development. However, a large amount of toxic trace elements (TTEs) emissions to the environment caused serious atmosphere, soil, water pollution, and human health issues during coal processing [1-3]. Furthermore, as one of the common TTEs in coal, chromium $(\mathrm{Cr})$ had been listed as hazardous air pollutants (HAPs) and had drawn special attention. $\mathrm{Cr}$ and its compounds were very easy to pollute water and soil. It could combine with hemoglobin through the red blood cell membrane. They would cause genetic defects and carcinogenesis and do great harm to humans [4]. Consequently, paying attention to the emission of $\mathrm{Cr}$ and other TTEs during coal combustion was of great significance for the development of clean coal technology and environmental protection.

Pyrolysis is an important initial step or intermediate process in coal combustion, gasification, and liquefaction [5]. In recent years, pyrolysis was considered as an effective and promising way for coal upgrading and removing TTEs before combustion. Hence, the pyrolysis technology had attracted increasing attention [6,7]. However, only a few pieces of literature had studied the release behavior of TTEs in coal during the pyrolysis 
process. For example, Guo et al. [8-10] investigated the effects of temperature, pyrolysis rate, atmosphere, and residence time on the volatility of TTEs in bituminous coal, and the modes of occurrence of elements were studied by the sequential chemical extraction (SCE). The author found that the volatility of TTEs increased with the rise of pyrolysis temperature and residence time, decreased at advanced pressure, and rapid pyrolysis rate. The $\mathrm{H}_{2}$ atmosphere was favorable for the evaporation of TTEs. The modes of occurrence might be a crucial factor for TTEs during pyrolysis. Khare et al. [11] reported the thermal behavior of trace elements at various temperatures in high sulfur coals and found that $\mathrm{Cr}$ showed variable affinity at different temperatures due to its interaction with carbon, sulfur, and chlorine. Wei et al. [12] studied the volatilization of TTEs during oxidative pyrolysis and modes of occurrence through SCE in anthracite coal. The results showed that the volatility of TTEs exhibited a close correlation with the modes of occurrence. Therefore, it was necessary to investigate the modes of occurrence of TTEs in coal besides the influence conditions of the pyrolysis process.

Many scholars had conducted researches on the release and transfer behaviors of TTEs in the coal combustion process. The release behavior of $\mathrm{Cr}$ and other TTEs during the coal combustion process had been extensively investigated [13-17]. For example, Zhang et al. [18] investigated the release behavior of $\mathrm{Cr}$ and other TTEs from coal in the initial stage of the combustion process. The author concluded that the volatility of elements mainly depended on the modes of occurrence of elements. A study by Wang [19] indicated that the volatilization of heavy metals was dependent on their thermochemical properties of themselves. Wang [20] studied the release and transformation of as during the cocombustion of coal and biomass as well as the effects of mineral elements in biomass on its volatilization. The results showed that the mineral elements inhibited the volatilization of arsenic when $\mathrm{Na}, \mathrm{K}, \mathrm{Mg}, \mathrm{Ca}, \mathrm{Al}, \mathrm{Fe}$, and $\mathrm{Si}$ were added to coal. This indicated that modes of occurrence of as in coal had an important influence on its release. According to this literature, the volatility or transfer behaviors of TTEs during coal combustion were not only dependent on their thermochemical property but also their modes of occurrence. Therefore, it was highly important to understand the modes of occurrence of TTEs in coal before coal combustion, gasification, and other coal processing.

The modes of occurrence of $\mathrm{Cr}$ and other TTEs in coal had been studied extensively by many scholars [21-25]. As the direct characterization method, XAFS and SEM-EDX were applied in researching modes of occurrence of TTEs. As the indirect method, statistical analysis, float-and-sink tests, and SCE were applied in investigating modes of occurrence of TTEs. However, indirect methods had been used commonly due to the extremely low content of TTEs in coal and the limitations of direct characterization methods [26]. The method of statistical analysis and float-and-sink tests were the physical method to study the modes of occurrence by obtaining the relationship between elements and organic matter and inorganic minerals. It lacks precision and theoretical depth. In addition, pyrolysis, as a thermochemical process, could also identify the modes of occurrence of TTEs in coal. Luo et al. [24,27] identified modes of occurrence of $\mathrm{Hg}$ in coal through temperature-programmed pyrolysis. Guo et al. [28,29] identified modes of occurrence of $\mathrm{Hg}$ in bituminous coal by combing temperature-programmed pyrolysis with the online atomic fluorescence spectrometry method. Thus, the temperature-programmed pyrolysis identified modes of occurrence of TTEs mainly based on the relationship between the decomposition temperature of specific inorganic minerals or organic matter with the release temperature range of TTEs. However, due to the diversity of modes of occurrence of TTEs in coal, the release temperature range of TTEs was too large. The peaks formed by the release of TTEs were broad and might overlap. Hence, it made it difficult to identify the specific forms and investigate their thermal ability. Besides, few authors studied the volatility characteristics or release behavior of TTEs in low-rank coal during the pyrolysis process [30,31]. Low-rank coal owned high volatile matter, reactivity, and low ash than highrank coal, which made a suitable material for coal chemistry. Therefore, it was extremely 
necessary to study the modes of occurrence and their release behavior of TTEs during the pyrolysis process for low-rank coal.

Thus, a single-component samples (SCS) pyrolysis method was proposed at present. The components containing single modes of occurrence of TTEs, called SCS, were prepared by SCE. It was able to accurately investigate the thermal stability of components containing single modes of occurrence of elements by the SCS pyrolysis. The advantage of SCE was able to identify and quantify the modes of occurrence of TTEs in coal by extracting a certain form of elements into selective acid or alkaline solutions through a chemical method. Therefore, modes of occurrence of TTEs in coal could be identified, quantified and their thermal stability could also be investigated more accurately by coupling SCE with SCS pyrolysis.

In the present study, two Chinese low-rank coal from Xinjiang province named NMH coal; Inner Mongolia named GL coal, and SCS were pyrolyzed in a fixed-bed reactor. The final temperature was $400-800{ }^{\circ} \mathrm{C}$ with an interval of $100^{\circ} \mathrm{C}$ at atmosphere pressure. The heating rate was $5{ }^{\circ} \mathrm{C} / \mathrm{min}$ and the residence time was $60 \mathrm{~min}$ at the final temperature. Modes of occurrence and preparation of SCS of $\mathrm{Cr}$ were carried out by SCE. The release behavior of $\mathrm{Cr}$ in raw coal and SCS was investigated during pyrolysis. Thermochemical equilibrium simulation software FactSage 7.3 was used to simulate the migration and transformation of $\mathrm{Cr}$ in two low-rank coal pyrolysis.

\section{Materials and Methods}

\subsection{Materials}

Two Chinese low-rank coal samples were used in the present study, named NMH coal (Xinjiang province) and GL coal (Inner Mongolia) separately. The two raw materials were crushed and milled to get the particle size less than $2 \mathrm{~mm}$. All samples were heated to $80^{\circ} \mathrm{C}$ and maintained at this temperature for $12 \mathrm{~h}$ in a vacuum-dried oven to remove the moisture. All coal samples were divided into two parts by division. One part was used for experiments, and the other part was split as the stored samples. The representative samples of raw coals were taken as proximate, ultimate, and XRF analyses. Results of proximate and ultimate analyses of raw coal samples are shown in Table 1. NMH and GL coal owned high volatile matter, showing its low-rank characteristic, and low ash content. Total sulfur content in GL was obviously higher than NMH coal. Results of XRF are shown in Table 2. $\mathrm{SiO}_{2}$ was the main ash composition, followed by $\mathrm{Al}_{2} \mathrm{O}_{3}, \mathrm{Fe}_{2} \mathrm{O}_{3}, \mathrm{CaO}$, and $\mathrm{SO}_{3}$ in $\mathrm{NMH}$ and GL coal.

Table 1. Analysis of samples.

\begin{tabular}{|c|c|c|c|c|c|c|c|c|c|c|c|}
\hline \multirow{2}{*}{ Sample } & \multirow{2}{*}{$\begin{array}{c}\mathrm{Cr}_{\mathrm{d}} \\
(\mu \mathrm{g} / \mathrm{g})\end{array}$} & \multirow{2}{*}{$\underset{(\mu \mathrm{g} / \mathrm{g})}{\mathrm{Cl}_{\mathrm{d}}}$} & \multicolumn{4}{|c|}{ Proximate Analysis (wt\%) } & \multicolumn{5}{|c|}{ Ultimate Analysis (wt\%) } \\
\hline & & & $\mathbf{M}_{\mathrm{ad}}$ & $\mathbf{A}_{\mathrm{d}}$ & $\mathrm{V}_{\text {daf }}$ & $F_{\text {daf }}$ & $\mathrm{C}_{\text {daf }}$ & $\mathbf{H}_{\text {daf }}$ & $\mathrm{O}_{\text {daf }}$ & $\mathbf{N}_{\text {daf }}$ & $S_{t, d a f}$ \\
\hline $\mathrm{NMH}$ & 5.22 & 60 & 9.16 & 9.95 & 52.76 & 47.24 & 77.41 & 6.60 & 13.23 & 2.16 & 0.60 \\
\hline GL & 14.56 & 910 & 10.13 & 12.13 & 38.49 & 61.51 & 76.72 & 5.07 & 15.39 & 0.81 & 2.01 \\
\hline
\end{tabular}

M: moisture; A: ash; V: volatile; FC: fix carbon; $\mathrm{S}_{\mathrm{t}}$ : total sulfur; ad: air-dry basis; d: dry basis; daf: dry and ash-free O: by difference.

Table 2. Ash composition in coal.

\begin{tabular}{ccccccccc}
\hline Sample & $\mathrm{SiO}_{\mathbf{2}}$ & $\mathrm{Al}_{\mathbf{2}} \mathbf{O}_{\mathbf{3}}$ & $\mathrm{Fe}_{\mathbf{2}} \mathbf{O}_{\mathbf{3}}$ & $\mathbf{C a O}$ & $\mathrm{Na}_{\mathbf{2}} \mathbf{O}$ & $\mathbf{M g O}$ & $\mathbf{K}_{\mathbf{2}} \mathbf{O}$ & $\mathrm{SO}_{\mathbf{3}}$ \\
\hline $\mathrm{NMH}$ & 39.35 & 16.64 & 5.88 & 23.30 & 2.95 & 1.23 & 0.38 & 8.83 \\
$\mathrm{GL}$ & 32.57 & 14.03 & 10.11 & 17.00 & 0.57 & 6.43 & 0.42 & 17.84 \\
\hline
\end{tabular}

\subsection{Materials Analysis}

Moisture, ash, volatile matter, and fixed carbon were determined according to the Chinese Standard Method GB/T 212-2008. The content of carbon, hydrogen, nitrogen, and sulfur were determined using a vario MACRO cube. XRF (XRF-1800) was employed to measure the concentrations of major element oxides in the coal ash sample. 
Mineralogical characteristics of $\mathrm{NMH}$ and GL raw coal were determined using XRD analysis. Low-temperature ash of coal samples was obtained by burning samples at $250{ }^{\circ} \mathrm{C}$ in a muffle furnace for $60 \mathrm{~h}$ prior to XRD analysis. Two raw coals were analyzed using a Japanese Rigaku D/max-2500PC X-ray diffractometer (Rigaku Corporation, Tokyo, Japan) with a $\mathrm{Cu}$ tube. The XRD pattern was recorded over a $2 \theta$ range of $5-70^{\circ}$ with a step size of $0.02^{\circ}$, the scanning speed was $2^{\circ} / \mathrm{min}$. The accelerating voltage and the tube current of the X-ray diffractometer were $40 \mathrm{kV}$ and $150 \mathrm{~mA}$, respectively. The XRD results of $\mathrm{NMH}$ and GL raw coal are shown in Figure 1. In NMH coal, kaolinite, quartz, anhydrite, and calcite had been identified, while kaolinite, quartz, anhydrite, calcite, pyrite had been identified in GL coal.

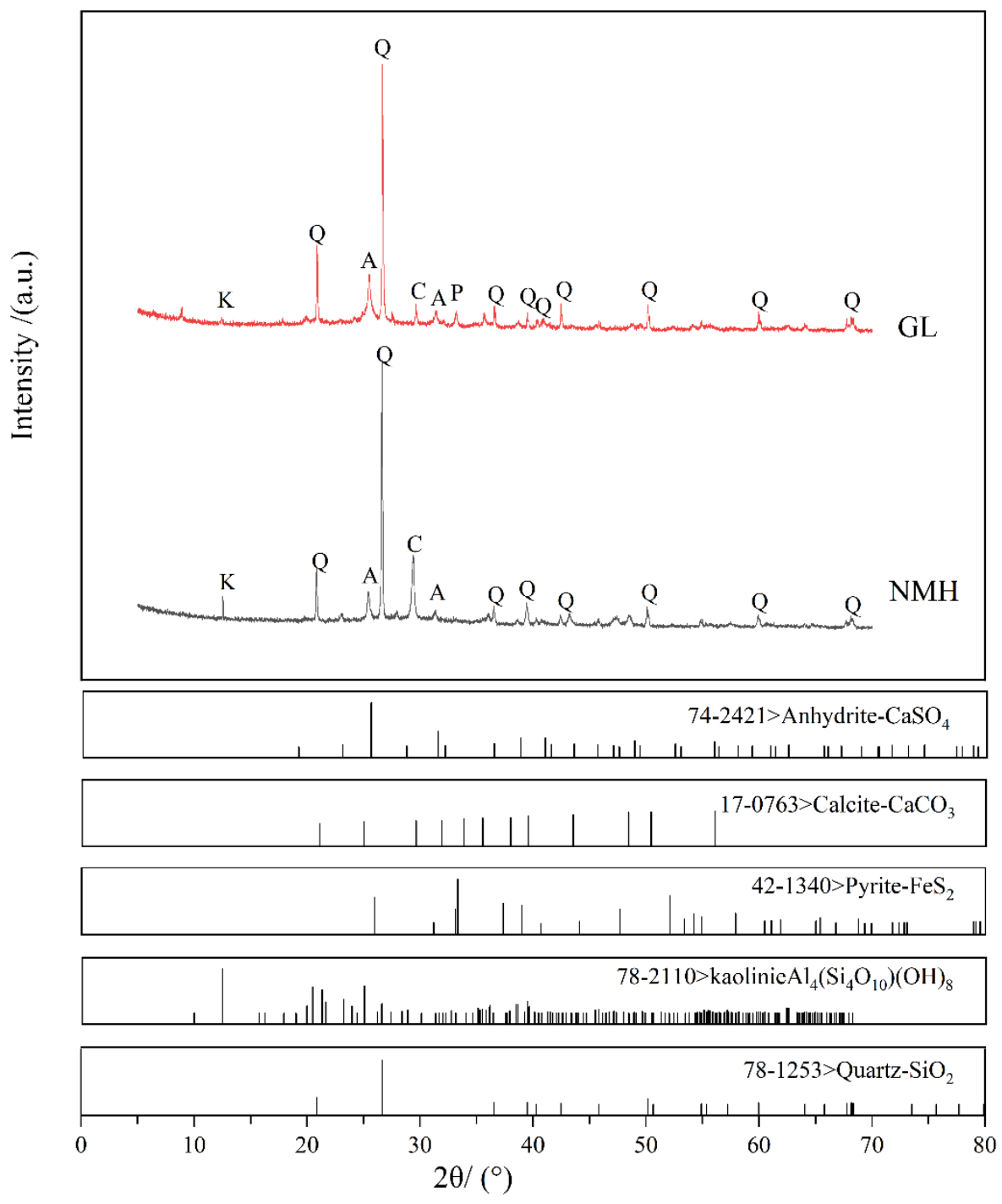

Figure 1. XRD patterns of low-temperature ash of NMH and GL. Q: quartz; A: anhydrite; K: kaolinite; P: pyrite; C: calcite.

\subsection{SEM-EDX Analysis}

The physical structure of the surface of NMH and GL coal were characterized by scanning electron microscopy (SEM)-energy dispersive X-ray spectrometer (EDX) (SU8020 Series). The results are shown in Figure 2. It found that pyrite, anhydrite, and aluminosilicate were easy to be identified in coal, but calcite was hard to be identified in GL coal. 


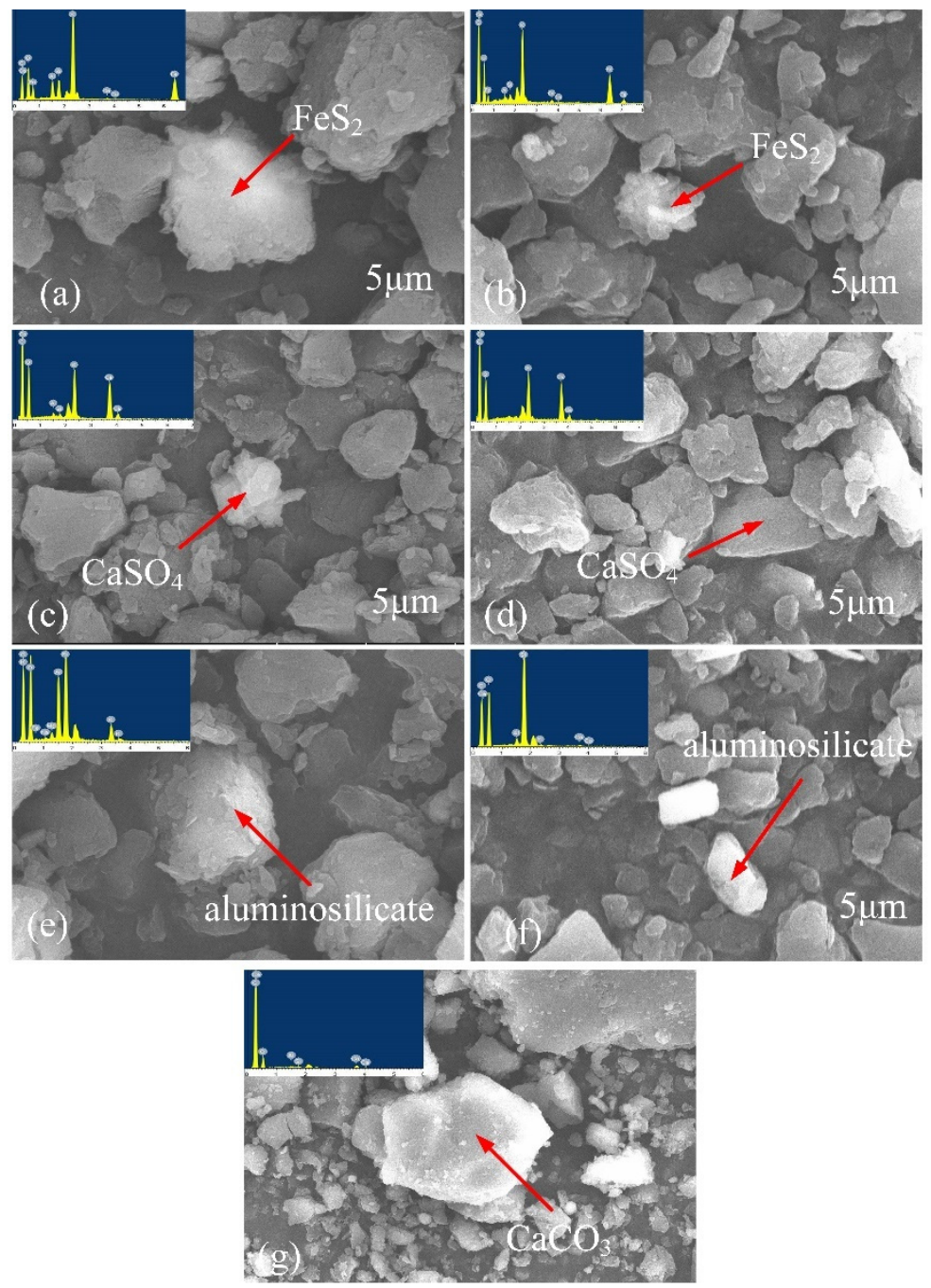

Figure 2. SEM-EDX images of minerals in $\mathrm{NMH}(\mathbf{a}, \mathbf{c}, \mathbf{e}, \mathbf{g})$ and $\mathrm{GL}(\mathbf{b}, \mathbf{d}, \mathbf{f})$ coal.

\subsection{Concentration Analysis of $\mathrm{Cr}$ and $\mathrm{Cl}$}

Samples were crushed and then ground to pass through a $74 \mu \mathrm{m}$ mesh for $\mathrm{Cr}$ and $\mathrm{Cl}$ analysis. The guaranteed reagents for $100 \mathrm{mg}$ sample digestion were $6 \mathrm{~mL} \mathrm{HNO}_{3}, 3 \mathrm{~mL}$ $\mathrm{H}_{2} \mathrm{O}_{2}$, and $3 \mathrm{~mL}$ HF. The microwave digestion procedures are presented in Table 3 . After the digestion by microwave digestion system, $\mathrm{Cr}$ concentration in samples was determined by using ICP-MS (NexlON300X). ICP-MS has good reproducibility and a low detection limit for the determination of trace elements [32]. Cl concentration in samples was determined using the ST-1 high-temperature hydrolysis chlorine analyzer according to the Chinese Standard Method GB/T 3558-2014. Prior to ICP-MS analysis, the samples were digested using the microwave digester (CEM MARS 5). The water used in the microwave digestion process was ultrapure water produced by the Milli- $\mathrm{Q}^{\mathrm{TM}} \mathrm{A} 10$ system to reduce the background value. All data of elements content were the average value through three measurements.

Table 3. The running program of microwave digester.

\begin{tabular}{ccccc}
\hline Stage & Power $(\mathbf{W})$ & Ramp $(\mathbf{m i n})$ & Temperature $\left({ }^{\circ} \mathbf{C}\right)$ & Hold $(\mathbf{m i n})$ \\
\hline 1 & 1600 & 8 & 120 & 4 \\
2 & 1600 & 8 & 160 & 5 \\
3 & 1600 & 5 & 185 & 25 \\
4 & \multicolumn{2}{c}{ Cooldown } \\
\hline
\end{tabular}




\subsection{SCE}

In this study, the above four guaranteed reagents in Section 2.4 were used to successively extract minerals and organic matter from raw coals. Specific extraction conditions and procedures are shown in Table 4 according to other scholars [33,34]. Through the experiment, $\mathrm{Cr}$ associated with different parts of the coal could be removed. Then, the extracts were measured by ICP-MS to investigate the modes of occurrence.

Table 4. Sequential chemical extraction procedures.

\begin{tabular}{ccccc}
\hline Step & Reagent & Time $/ \mathbf{h}$ & Temperature $/{ }^{\circ} \mathbf{C}$ & Occurrence Modes \\
\hline 1 & $5 \mathrm{~mol} / \mathrm{L} \mathrm{HCl}$ & 6 & 60 & Bound to carbonate \\
2 & $40 \% \mathrm{HF}$ & 6 & 60 & Bound to aluminosilicate \\
3 & $5 \mathrm{~mol} / \mathrm{L} \mathrm{HNO}_{3}$ & 6 & 45 & Bound to disulfide \\
4 & $30 \% \mathrm{H}_{2} \mathrm{O}_{2}$ & 6 & 85 & Bound to organic matter \\
\hline
\end{tabular}

The modes of occurrence of $\mathrm{Cr}$ in coal could be divided into four categories: $\mathrm{Cr}$ bounded to carbonates (including monosulfide, sulfate, phosphate, and oxide, the same below), $\mathrm{Cr}$ bounded to aluminosilicate, $\mathrm{Cr}$ bounded to disulfide and $\mathrm{Cr}$ bounded to organic matter. To investigate the thermal stability of various occurrence modes of $\mathrm{Cr}, \mathrm{NMH}$, and GL raw coal were extracted by $\mathrm{HCl} / \mathrm{HNO}_{3} / \mathrm{H}_{2} \mathrm{O}_{2}, \mathrm{HCl} / \mathrm{HF} / \mathrm{H}_{2} \mathrm{O}_{2}, \mathrm{HCl} / \mathrm{HF} / \mathrm{HNO}_{3}$ in three different order. Therefore, three SCS containing a single occurrence mode of $\mathrm{Cr}$ were obtained, which were recorded as $\mathrm{HCl} / \mathrm{HNO}_{3} / \mathrm{H}_{2} \mathrm{O}_{2}-\mathrm{NMH}(\mathrm{GL}), \mathrm{HCl} / \mathrm{HF} / \mathrm{H}_{2} \mathrm{O}_{2}-\mathrm{NMH}$ (GL), $\mathrm{HCl} / \mathrm{HF} / \mathrm{HNO}_{3}-\mathrm{NMH}(\mathrm{GL})$, respectively. The three samples represented $\mathrm{Cr}$ bounded to aluminosilicate, $\mathrm{Cr}$ bounded to disulfide and $\mathrm{Cr}$ bounded to organic matter, separately. It was a pity that the sample of $\mathrm{Cr}$ bounded to carbonates could not be obtained by this method due to the addition of $\mathrm{HCl}$.

\subsection{TG Analysis}

To investigate the release behavior of $\mathrm{Cr}$ during the pyrolysis process, pyrolysis behaviors of $\mathrm{NMH}$ and GL coal in TGA at $10^{\circ} \mathrm{C} / \mathrm{min}$ from room to $900{ }^{\circ} \mathrm{C}$ and atmospheric pressure were studied by utilizing TG and DTG plots. The TGA was carried out using a Mettler-Toledo TGA/DSC 1 thermogravimetric analyzer. Nitrogen was used as the carrier gas (at $50 \mathrm{~mL} / \mathrm{min}$ ) to ensure an oxygen-free environment.

\subsection{Pyrolysis}

Pyrolysis experiments of NMH and GL raw coal, as well as SCS, were conducted in a fixed-bed reactor as schematically illustrated in Figure 3. Approximately $20 \mathrm{~g}$ of coal samples were weighed and placed into a quartz crucible. Highly pure nitrogen $(99.999 \%)$ was introduced to the quartz crucible, and the reaction zone was closed. Then, it was heated from ambient temperature to final temperature of $400-800{ }^{\circ} \mathrm{C}$ with an interval of $100{ }^{\circ} \mathrm{C}$. The heating rate was $5{ }^{\circ} \mathrm{C} / \mathrm{min}$ and the residence time was $60 \mathrm{~min}$. Nitrogen gas was introduced into the reactor at a flow rate of $50 \mathrm{~mL} / \mathrm{min}$ to sweep the volatile products out of the reactor. Subsequently, char samples were obtained from pyrolysis at the different pyrolysis temperatures of $400,500,600,700$, and $800^{\circ} \mathrm{C}$. Char samples were weighed and stored hermetically after the quartz crucible cooled to ambient temperature. 


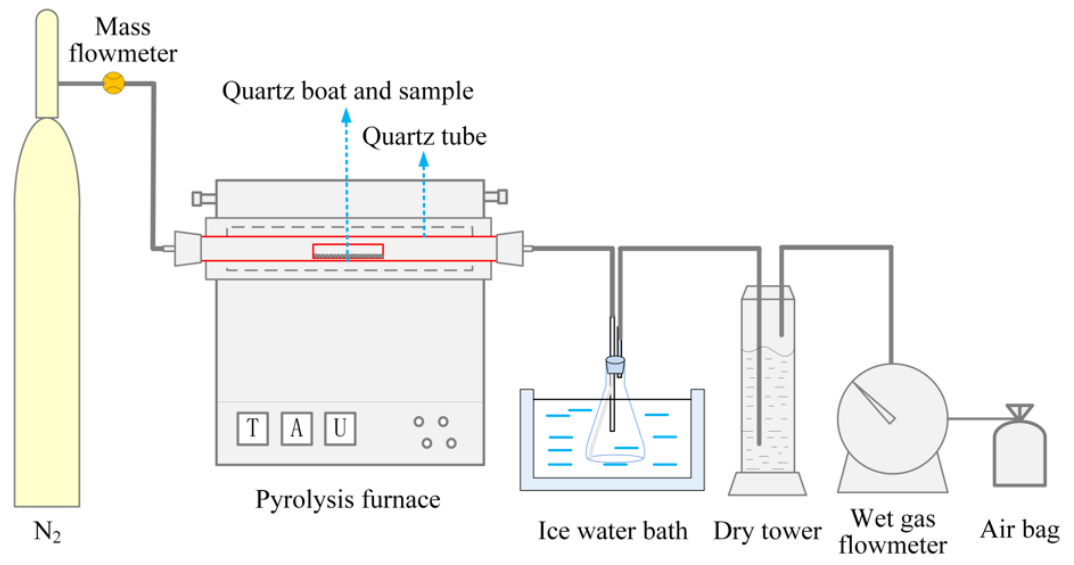

Figure 3. Schematic diagram of tube furnace pyrolysis device.

\subsection{Release Ratio and Extraction Ratio of $\mathrm{Cr}$}

The release ratio of $\mathrm{Cr}$ was used to evaluate the release extent of the $\mathrm{Cr}$ during coal pyrolysis and was defined as:

$$
R r=\left(C_{\text {rawcoal }}-C_{\text {char }}\right) / C_{\text {rawcoal }} * 100 \%
$$

where $R r$ was the release ratio of $\mathrm{Cr}, \mathrm{C}_{\text {rawcoal }}$ was the content of $\mathrm{Cr}$ in raw coal, $\mathrm{C}_{\text {char }}$ was the content of $\mathrm{Cr}$ in char. The content of $\mathrm{Cr}$ in coal or char was obtained by the concentration of Cr measured multiplied by the mass of raw coal or char.

To evaluate the extraction ability of different extraction processes for $\mathrm{Cr}$ and organic/inorganic matter, the concept of extraction ratio was introduced, which was defined as:

$$
E r=C_{\text {extracts }} / C_{\text {rawcoal }} * 100 \%
$$

where $\mathrm{Er}$ was the extraction ratio of the $\mathrm{Cr}$ or minerals, $\mathrm{C}_{\text {extracts }}$ was the content of $\mathrm{Cr}$ or minerals in the extracts, $C_{\text {rawcoal }}$ was the content of $\mathrm{Cr}$ or minerals in raw coal.

\subsection{Thermochemical Equilibrium Simulation}

The Equilib module of FactSage thermochemical calculation software was able to use Gibbs free energy minimum principle to calculate mineral phase in the equilibrium state. In this paper, FactSage 7.3 was used to simulate the migration and transformation of Cr during NMH and GL coal pyrolysis. Before calculation, two databases of FactPS and FToxide under Datasearch were selected firstly. In the calculation, it was assumed that a $100 \mathrm{~g}$ coal sample was used, and content of $\mathrm{C}, \mathrm{H}, \mathrm{O}, \mathrm{N}, \mathrm{S}, \mathrm{Cr}, \mathrm{Cl}$, and the major components of coal ash was used to represent the coal. The $\mathrm{N}_{2}$ value was $500 \mathrm{~g}$, the pressure was $1 \mathrm{~atm}$, the simulated temperature was $300-900{ }^{\circ} \mathrm{C}$ and the temperature interval was $100{ }^{\circ} \mathrm{C}$. The specific input value of elements and oxides in coal is shown in Table 5.

\begin{tabular}{|c|c|c|c|c|c|}
\hline \multirow{2}{*}{ Element } & \multicolumn{2}{|c|}{ Mass/g } & \multirow{2}{*}{$\begin{array}{c}\text { Ash } \\
\text { Composition }\end{array}$} & \multicolumn{2}{|c|}{ Mass/g } \\
\hline & NMH & GL & & NMH & GL \\
\hline $\mathrm{C}$ & 77.41 & 76.72 & $\mathrm{SiO}_{2}$ & 3.92 & 3.95 \\
\hline $\mathrm{H}$ & 6.60 & 5.07 & $\mathrm{Al}_{2} \mathrm{O}_{3}$ & 1.66 & 1.70 \\
\hline $\mathrm{O}$ & 13.23 & 15.39 & $\mathrm{CaO}$ & 2.32 & 2.06 \\
\hline $\mathrm{N}$ & 2.16 & 0.81 & $\mathrm{SO}_{3}$ & 0.88 & 2.16 \\
\hline S & 0.60 & 2.01 & $\mathrm{MgO}$ & 0.12 & 0.78 \\
\hline $\mathrm{Cr}$ & $5.22 \mathrm{E}-4$ & $1.46 \mathrm{E}-3$ & $\mathrm{~K}_{2} \mathrm{O}$ & 0.04 & 0.05 \\
\hline $\mathrm{Cl}$ & $6.00 \mathrm{E}-3$ & $9.10 \mathrm{E}-2$ & $\mathrm{Na}_{2} \mathrm{O}$ & 0.29 & 0.07 \\
\hline & & & $\mathrm{Fe}_{2} \mathrm{O}_{3}$ & 0.59 & 1.23 \\
\hline
\end{tabular}

Table 5. Initial input value for calculation. 


\section{Results and Discussion}

\subsection{Modes of Occurrence of $\mathrm{Cr}$}

The results of the extraction ratio of minerals and organic matter in NMH and GL raw coals are presented in Figure 4 a. 37.7\% and $42.9 \%$ carbonate in two coals were extracted with $5 \mathrm{~mol} / \mathrm{L} \mathrm{HCl}$ respectively. 59.3\% and 52.7\% aluminosilicate were extracted with $40 \% \mathrm{HF}$ separately. $2.8 \%$ and $3.9 \%$ disulfide were extracted with $5 \mathrm{~mol} / \mathrm{L} \mathrm{HNO}_{3}$ respectively. The remaining $0.2 \%$ and $0.5 \%$ of minerals remained in raw coals. It could be concluded that most of the residues in raw coal extracted by $\mathrm{HCl} / \mathrm{HF} / \mathrm{HNO}_{3}$ were the organic matter. Therefore, the main inorganic minerals in the two coals were aluminosilicate and carbonate, accounting for $97 \%$ and $95.6 \%$, respectively. They were consistent with the results of XRD and XRF (Figure 1 and Table 2).
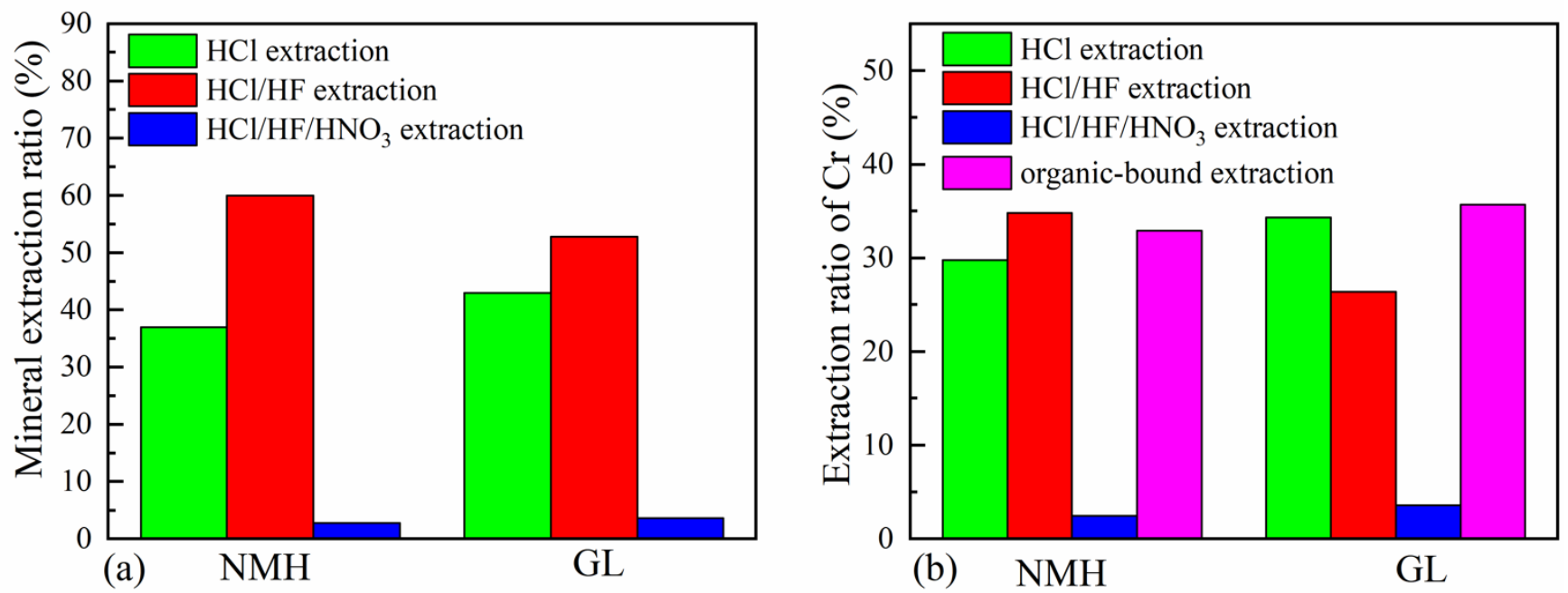

Figure 4. Extraction ratio of minerals and organic matter (a) and $\mathrm{Cr}(\mathbf{b})$ in NMH and GL coal.

The results of the extraction ratio of $\mathrm{Cr}$ in two coals are presented in Figure $4 \mathrm{~b}$. the relationship of $\mathrm{Cr}$ content in $\mathrm{NMH}$ coal among the various modes of occurrence in order was $\mathrm{Cr}$ bounded to aluminosilicate $(34.8 \%)>\mathrm{Cr}$ bounded to organic matter $(32.9 \%)>\mathrm{Cr}$ bounded to carbonate $(29.8 \%)>\mathrm{Cr}$ bounded to disulfide $(2.5 \%)$. For GL coal, the order was $\mathrm{Cr}$ bounded to organic matter $(35.7 \%)>\mathrm{Cr}$ bounded to carbonate $(34.3 \%)>\mathrm{Cr}$ bounded to aluminosilicate $(26.4 \%)>\mathrm{Cr}$ bounded to disulfide $(3.6 \%)$. Therefore, organic matter, aluminosilicate, carbonate were the main modes of occurrence of $\mathrm{Cr}$ in the coal, only a small part of $\mathrm{Cr}$ occurred in disulfide. This result was similar to the results of other reports on low-rank coal [35-37]. However, the major modes of occurrence of $\mathrm{Cr}$ in high-rank coal (bituminous and anthracite coal) were aluminosilicate minerals [8,38].

\subsection{Pyrolysis Experiment}

\subsubsection{Pyrolysis in Thermogravimetric Analyzer}

To investigate the release behavior of $\mathrm{Cr}$, the pyrolysis behavior of two coals was studied by TGA. In Figure 5a, the maximum mass loss of NMH and GL raw coal was about $60 \mathrm{wt} \%$ and $40 \mathrm{wt} \%$, respectively. The mass loss of NMH coal was always higher than GL coal in the whole process of thermal decomposition. It was mainly depending on their different volatiles and ash content (Table 1). The higher the volatile matter was, the more unstable side chains and oxygen-containing functional groups were in coal, and the easier to decompose at high temperatures. The first stage was from the beginning to around $200{ }^{\circ} \mathrm{C}$, where only water and a few peripheral mobile phases from the macromolecular structure decomposed. The second stage was from 200 to about $600{ }^{\circ} \mathrm{C}$, where a large mass loss of NMH and GL coal, approximately $33 w t \%$ and $20 w t \%$, was produced. The maximum decomposition peak of the two coals was shown at around $450{ }^{\circ} \mathrm{C}$ at the same 
time, corresponding to the sharp decrease in the TG plot. This phenomenon was caused by a large amount of volatiles produced in a narrow temperature range. As low-rank coal, there were a higher number of oxygen-containing functional groups contained in it, which could decompose quickly at moderate temperature. This could cause the release of TTEs bound to organic matter. The third stage was from 600 to $900{ }^{\circ} \mathrm{C}$. The remaining macromolecular structures in coal were mainly dense polycyclic aromatic compounds in the immobile phase. Then they were further decomposed at a relatively lower rate and produced about $16 \mathrm{wt} \%(\mathrm{NMH})$ and $12 \mathrm{wt} \%(\mathrm{GL})$ volatile matter. At high temperatures, some minerals would decompose or transform, leading to the release of TTEs associated with these minerals.
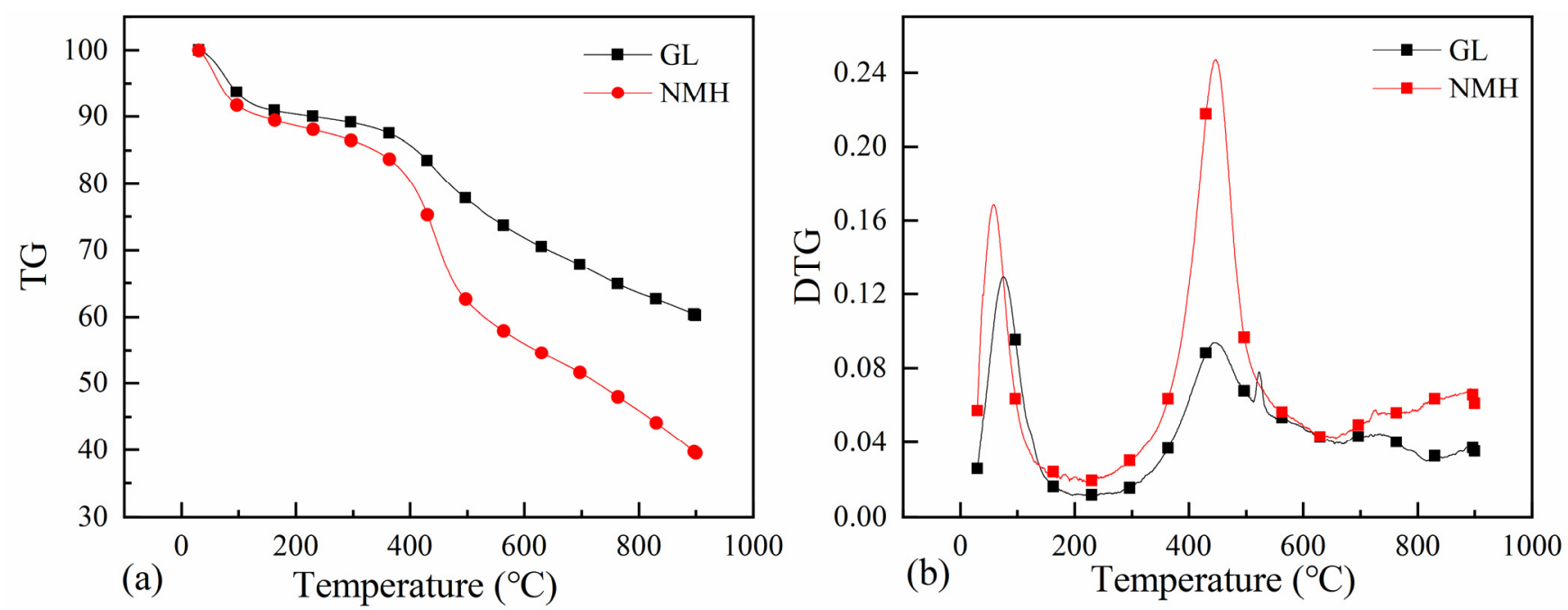

Figure 5. Pyrolysis behavior NMH and GL raw coal in TG (a) and DTG (b).

\subsubsection{Pyrolysis in Fixed-Bed Reactor}

To investigate the release behavior of $\mathrm{Cr}$, the pyrolysis behavior of NMH and GL raw coal was studied by a fixed-bed reactor. The chars yield of coal during the pyrolysis process are shown in Table 6 . With the increase in the pyrolysis final temperature, the chars yield of $\mathrm{NMH}$ and GL coal decreased gradually, from $70 \%$ at $400{ }^{\circ} \mathrm{C}$ to $51 \%$ at $800{ }^{\circ} \mathrm{C}$, and from $78 \%$ at $400{ }^{\circ} \mathrm{C}$ to $61 \%$ at $800{ }^{\circ} \mathrm{C}$, respectively. The reason why the char yields of GL coal were always higher than that of NMH coal was that the ash content of GL coal was higher than that of NMH coal, while the volatile matter of GL coal was lower than that of NMH coal.

Table 6. Char yields of NMH and GL raw coal in pyrolysis.

\begin{tabular}{cccccc}
\hline $\begin{array}{c}\text { Char } \\
\text { Yield/\% }\end{array}$ & $\mathbf{4 0 0}{ }^{\circ} \mathbf{C}$ & $\mathbf{5 0 0}{ }^{\circ} \mathbf{C}$ & $\mathbf{6 0 0}{ }^{\circ} \mathbf{C}$ & $\mathbf{7 0 0}{ }^{\circ} \mathbf{C}$ & $\mathbf{8 0 0}{ }^{\circ} \mathbf{C}$ \\
\hline NMH & 73.06 & 64.33 & 59.24 & 56.45 & 55.72 \\
GL & 78.65 & 68.31 & 66.01 & 62.83 & 61.64 \\
\hline
\end{tabular}

\subsection{Release Behavior of Cr in Raw Coal}

The release ratio and reaction rate (by fitting) of $\mathrm{Cr}$ during pyrolysis of NMH and GL coal are shown in Figure 6. The release ratio of $\mathrm{Cr}$ increased with the rising of temperature. Besides, the release ratio of $\mathrm{Cr}$ in GL coal was higher than that in $\mathrm{NMH}$ coal, from 3.87\% to $25.24 \%(\mathrm{GL})$ and $3.98 \%$ to $8.53 \%(\mathrm{NMH})$, respectively, in $400-800{ }^{\circ} \mathrm{C}$. The higher release ratio of $\mathrm{Cr}$ in GL coal was due to the more content of $\mathrm{Cr}$ bound to organic matter and less content of minerals associated form of $\mathrm{Cr}$ in GL coal. Besides, $\mathrm{Cl}$ was likely to be the reason for this phenomenon, which would be discussed in detail in Section 3.4.1. In Figure 6b, the reaction rate of $\mathrm{Cr}$ in $\mathrm{NMH}$ coal increased before $600{ }^{\circ} \mathrm{C}$, then decreased between 600 to $700{ }^{\circ} \mathrm{C}$, finally increased again after $800^{\circ} \mathrm{C}$, and changed little during the whole pyrolysis 
temperature range. However, the reaction rate of $\mathrm{Cr}$ in GL coal decreased slowly before $450{ }^{\circ} \mathrm{C}$, then sharply increased between 450 to $650{ }^{\circ} \mathrm{C}$, finally decreased rapidly after $650{ }^{\circ} \mathrm{C}$.
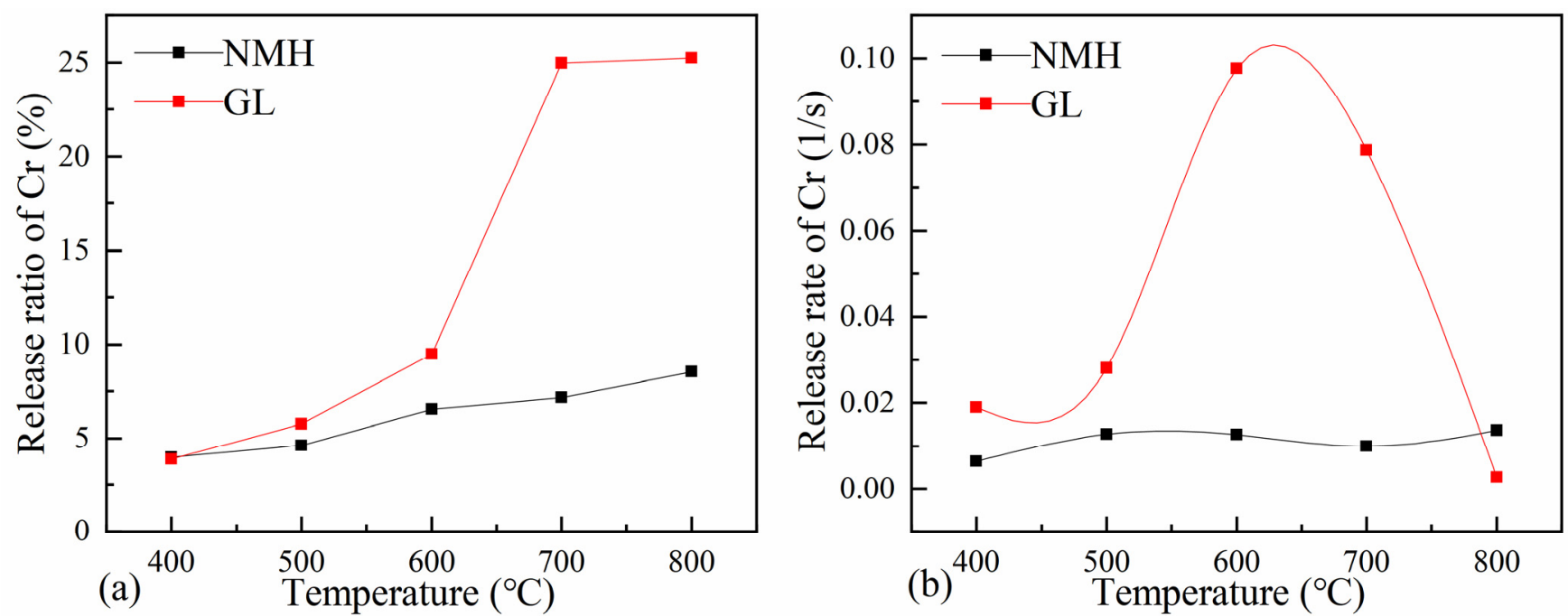

Figure 6. The release behavior (a) and reaction rate (b) of $\mathrm{Cr}$ at different final temperatures during pyrolysis.

As is shown in Figure 4, the Cr bounded to disulfide accounted for 3.6\% of the $\mathrm{Cr}$ content in GL raw coal. During the entire pyrolysis process, the release ratio of Cr in GL coal was about $25.24 \%$. It was assumed that the $\mathrm{Cr}$ bounded to disulfide was completely decomposed and released, the $\mathrm{Cr}$ bounded to disulfide accounted for $14.26 \%$ of the total $\mathrm{Cr}$ release from the raw coal. The release ratio of $\mathrm{Cr}$ in GL was $15.49 \%$ from 600 to $700{ }^{\circ} \mathrm{C}$, which was consistent with the content of $\mathrm{Cr}$ bounded to a disulfide. Moreover, pyrite, as the main component of disulfide, began to decompose after $500{ }^{\circ} \mathrm{C}$ [12]. Therefore, it was concluded that the sharp increase in the release ratio and reaction rate of $\mathrm{Cr}$ in GL coal instead of $\mathrm{Cr}$ in $\mathrm{NMH}$ coal was mainly due to the decomposition of disulfide, considering the reaction rate at $600^{\circ} \mathrm{C}$.

\subsection{Release Behavior of Cr in SCS}

To investigate the effect of occurrence modes of $\mathrm{Cr}$ on its release behavior, the pyrolysis behavior of SCS obtained by SCE was studied in the fixed-bed reactor and shown in Figure 7. The release ratio of $\mathrm{Cr}$ was calculated based on $\mathrm{Cr}$ content in each SCS.

\subsubsection{Release Behavior of $\mathrm{Cr}$ in $\mathrm{HCl} / \mathrm{HNO}_{3} / \mathrm{H}_{2} \mathrm{O}_{2}$-Sample Pyrolysis}

$\mathrm{Cr}$ in $\mathrm{HCl} / \mathrm{HNO}_{3} / \mathrm{H}_{2} \mathrm{O}_{2}$-sample presented as the $\mathrm{Cr}$ bounded to aluminosilicate. As is shown in Figure $7 \mathrm{a}$, the release ratio of $\mathrm{Cr}$ in $\mathrm{HCl} / \mathrm{HNO}_{3} / \mathrm{H}_{2} \mathrm{O}_{2}-\mathrm{NMH}$ increased from $2.35 \%$ to $9.86 \%$ with the increasement of pyrolysis temperature. It showed that $\mathrm{Cr}$ in $\mathrm{HCl} / \mathrm{HNO}_{3} / \mathrm{H}_{2} \mathrm{O}_{2}-\mathrm{NMH}$ was released after $600{ }^{\circ} \mathrm{C}$. The release temperature was higher than that for $\mathrm{Cr}$ in $\mathrm{HCl} / \mathrm{HF} / \mathrm{H}_{2} \mathrm{O}_{2}-\mathrm{NMH}$ and $\mathrm{HCl} / \mathrm{HF} / \mathrm{HNO}_{3}-\mathrm{NMH}$ coal. The high release temperature should be attributed to the higher thermal stability of $\mathrm{Cr}$ [11] and aluminosilicate in coal. The $\mathrm{Cr}$ bounded to aluminosilicate was difficult to dissociate and release in the middle and low-temperature regions. Even at high temperatures, a large part of the $\mathrm{Cr}$ existed in the solid residue together with aluminosilicate $[8,12]$.

As is shown in Figure $7 \mathrm{~b}$, the release ratio of $\mathrm{Cr}$ in $\mathrm{HCl} / \mathrm{HNO}_{3} / \mathrm{H}_{2} \mathrm{O}_{2}-\mathrm{GL}$ increased from $1.37 \%$ to $61.56 \%$ with the increasement of pyrolysis temperature. $\mathrm{Cr}$ in $\mathrm{HCl} / \mathrm{HNO}_{3} / \mathrm{H}_{2} \mathrm{O}_{2}-$ $\mathrm{GL}$ released after $500{ }^{\circ} \mathrm{C}$. The release temperature of $\mathrm{Cr}$ in $\mathrm{HCl} / \mathrm{HNO}_{3} / \mathrm{H}_{2} \mathrm{O}_{2}-\mathrm{GL}$ was lower than that for $\mathrm{Cr}$ in $\mathrm{HCl} / \mathrm{HNO}_{3} / \mathrm{H}_{2} \mathrm{O}_{2}-\mathrm{NMH}$ and the release ratio of $\mathrm{Cr}$ in $\mathrm{HCl} / \mathrm{HNO}_{3} / \mathrm{H}_{2} \mathrm{O}_{2}$ GL was obviously higher than that for $\mathrm{Cr}$ in $\mathrm{HCl} / \mathrm{HNO}_{3} / \mathrm{H}_{2} \mathrm{O}_{2}-\mathrm{NMH}$. The reason for this phenomenon was probably due to the high content of $\mathrm{Cl}$ in $\mathrm{GL}$ coal (Table 1). The $\mathrm{Cl}$ in 
coal reacted with $\mathrm{H}_{2}$ produced by pyrolysis to produce reducing gas, such as $\mathrm{HCl}$, and the reducing gas reacted with $\mathrm{Cr}$ bounded minerals to produce $\mathrm{Cr}$ chloride with a lower boiling point, enhancing the volatility of $\mathrm{Cr}$ and reducing the volatilization temperature of $\mathrm{Cr}[12,13]$. Another reason might be attributed to the mineral eutectic occurring between $\mathrm{SiO}_{2}, \mathrm{Al}_{2} \mathrm{O}_{3}$, and $\mathrm{CaO}$ [39], which could absorb and prevent the escape of elements. It was worth noting that the content of $\mathrm{SiO}_{2}, \mathrm{Al}_{2} \mathrm{O}_{3}$, and $\mathrm{CaO}$ in $\mathrm{NMH}$ coal was higher than that in GL coal. Thus, this was also the reason why the volatilization ratio of $\mathrm{Cr}$ was higher in GL raw coal during the pyrolysis process.
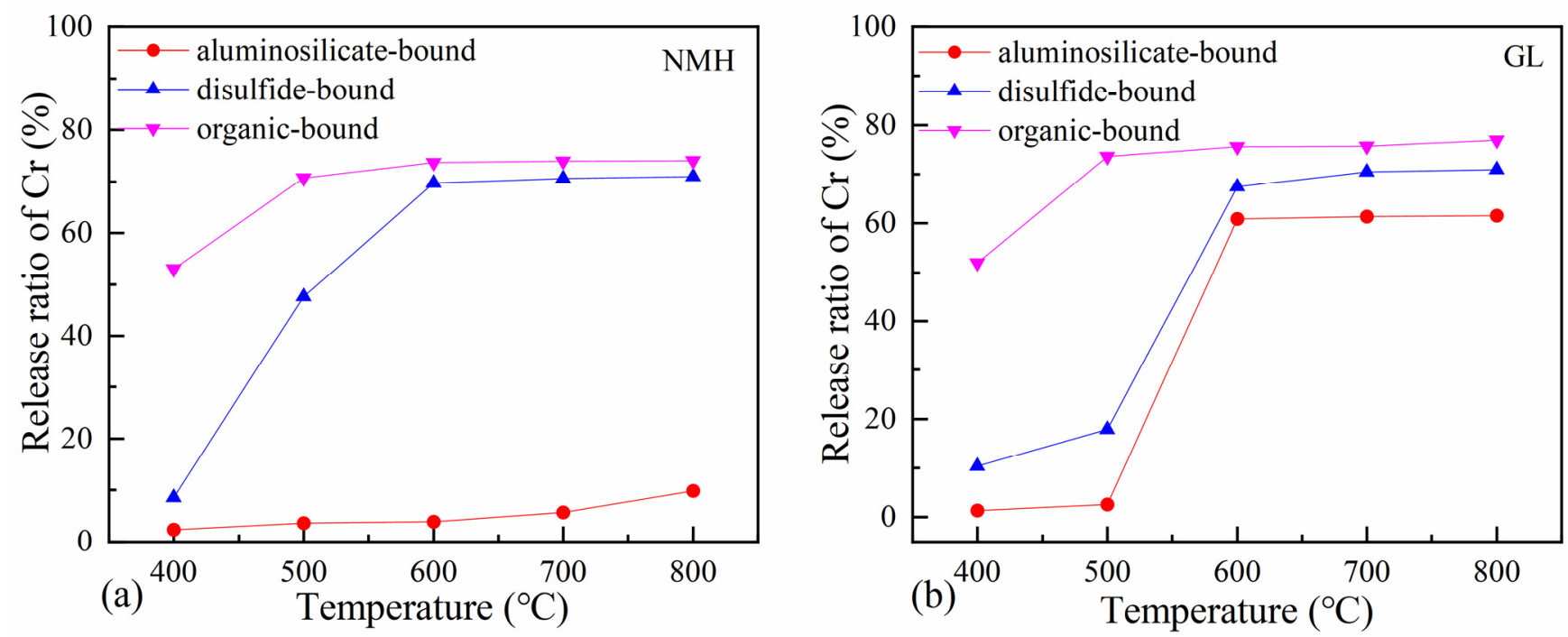

Figure 7. Release behavior of Cr in different SCS of NMH (a) and GL (b).

\subsubsection{Release Behavior of $\mathrm{Cr}$ in $\mathrm{HCl} / \mathrm{HF} / \mathrm{H}_{2} \mathrm{O}_{2}$-Sample Pyrolysis}

$\mathrm{Cr}$ in $\mathrm{HCl} / \mathrm{HF} / \mathrm{H}_{2} \mathrm{O}_{2}$-sample presented as the $\mathrm{Cr}$ bounded to disulfide (mainly pyrite). The release ratio of $\mathrm{Cr}$ in $\mathrm{HCl} / \mathrm{HF} / \mathrm{H}_{2} \mathrm{O}_{2}-\mathrm{NMH}$ and $\mathrm{GL}$ was $8.63-70.97 \%$ and $10.34-70.92 \%$ separately in the range of $400-800{ }^{\circ} \mathrm{C}$. The release temperature range was 400 to $600{ }^{\circ} \mathrm{C}$ for $\mathrm{Cr}$ bounded to disulfide due to the decomposition temperature of pyrite being around $500{ }^{\circ} \mathrm{C}$. During the thermal treatment process, $\mathrm{FeS}_{2}$ was oxidized to form $\mathrm{Fe}_{2} \mathrm{O}_{3}$ and $\mathrm{SO}_{2}$ between $490{ }^{\circ} \mathrm{C}$ and $690{ }^{\circ} \mathrm{C}$ [12]. Therefore, $\mathrm{Cr}$ bounded to disulfide dissociated and released at a temperature range of $400-600{ }^{\circ} \mathrm{C}$ accompanied by the decomposition of pyrite.

\subsubsection{Release Behavior of $\mathrm{Cr}$ in $\mathrm{HCl} / \mathrm{HF} / \mathrm{HNO}_{3}$-Sample Pyrolysis}

$\mathrm{Cr}$ in $\mathrm{HCl} / \mathrm{HF} / \mathrm{HNO}_{3}$-sample presented as the $\mathrm{Cr}$ bounded to organic matter. The release ratio of $\mathrm{Cr}$ in $\mathrm{HCl} / \mathrm{HF} / \mathrm{HNO}_{3}-\mathrm{NMH}$ and $\mathrm{GL}$ was $53.06-74.01 \%$ and $51.98-76.93 \%$, respectively, in the range of $400-800{ }^{\circ} \mathrm{C}$. Cr bounded to organic matter was almost completely released within $600{ }^{\circ} \mathrm{C}$. Based on the TGA results of NMH and GL coal (Figure 5), a large number of oxygen-containing functional groups decomposed at $200-600^{\circ} \mathrm{C}$ caused the release of TTEs bounded to organic matter. $\mathrm{Cr}$ bounded organic matter was usually covalently bonded with carboxyl (-COOH), hydroxyl $(-\mathrm{OH})$, and imino $(-\mathrm{NH})$ functional groups [12]. These organic functional groups had poor thermal stability and generally disappeared with the increase in pyrolysis temperature at low temperatures [5].

\subsection{Thermochemical Equilibrium Simulation}

To obtain a more insight study on the release and transfer behavior of $\mathrm{Cr}$, Global chemical equilibrium calculations were performed utilizing the program FactSage 7.3. It calculated the conversion behavior of $\mathrm{Cr}$ at different temperatures during the pyrolysis process. Thermochemical calculation results of $\mathrm{Cr}$ in $\mathrm{NMH}$ and GL coal are shown in Figure 8. In Figure $8 \mathrm{a}, \mathrm{b}$, it indicated that gas products were chlorides $\left(\mathrm{CrCl}, \mathrm{CrCl}_{2}, \mathrm{CrCl}_{3}\right.$, $\left.\mathrm{CrCl}_{4}, \mathrm{CrCl}_{5}, \mathrm{CrCl}_{6}\right)$, hydroxides $\left(\mathrm{Cr}(\mathrm{OH}), \mathrm{Cr}(\mathrm{OH})_{2}, \mathrm{Cr}(\mathrm{OH})_{3}, \mathrm{Cr}(\mathrm{OH})_{4}\right), \mathrm{Cr}$, $\mathrm{CrS}$, and 
oxides $\left(\mathrm{CrO}, \mathrm{CrO}_{2}, \mathrm{CrO}_{3}\right)$, among which chlorides was the dominant product. The chlorides content of $\mathrm{Cr}$ in GL was higher than that of $\mathrm{NMH}$ in the simulation process due to the higher content of $\mathrm{Cl}$ in GL coal (Table 1). On the contrary, the content of solid products remaining in chars such as $\mathrm{CrO}, \mathrm{Cr}_{2} \mathrm{O}_{3}, \mathrm{CrS}$, and $\mathrm{Cr}_{2} \mathrm{~S}_{3}$, was higher as shown in Figure $8 \mathrm{c}, \mathrm{d}$. This indicated that $\mathrm{Cr}$ had good thermal stability and was not easy to volatilize, and most of it remained in the char in the above forms (Figure 6). Besides, the calculation results showed that solid products were mainly sulfides and oxides of $\mathrm{Cr}$. They were closely related to the dominant form in the mineral-associated form of $\mathrm{Cr}$, carbonate, and the aluminosilicateassociated form (Figure $4 \mathrm{~b}$ ), in NMH and GL coal. The equilibrium calculation results mentioned above were consistent with the experimental results.
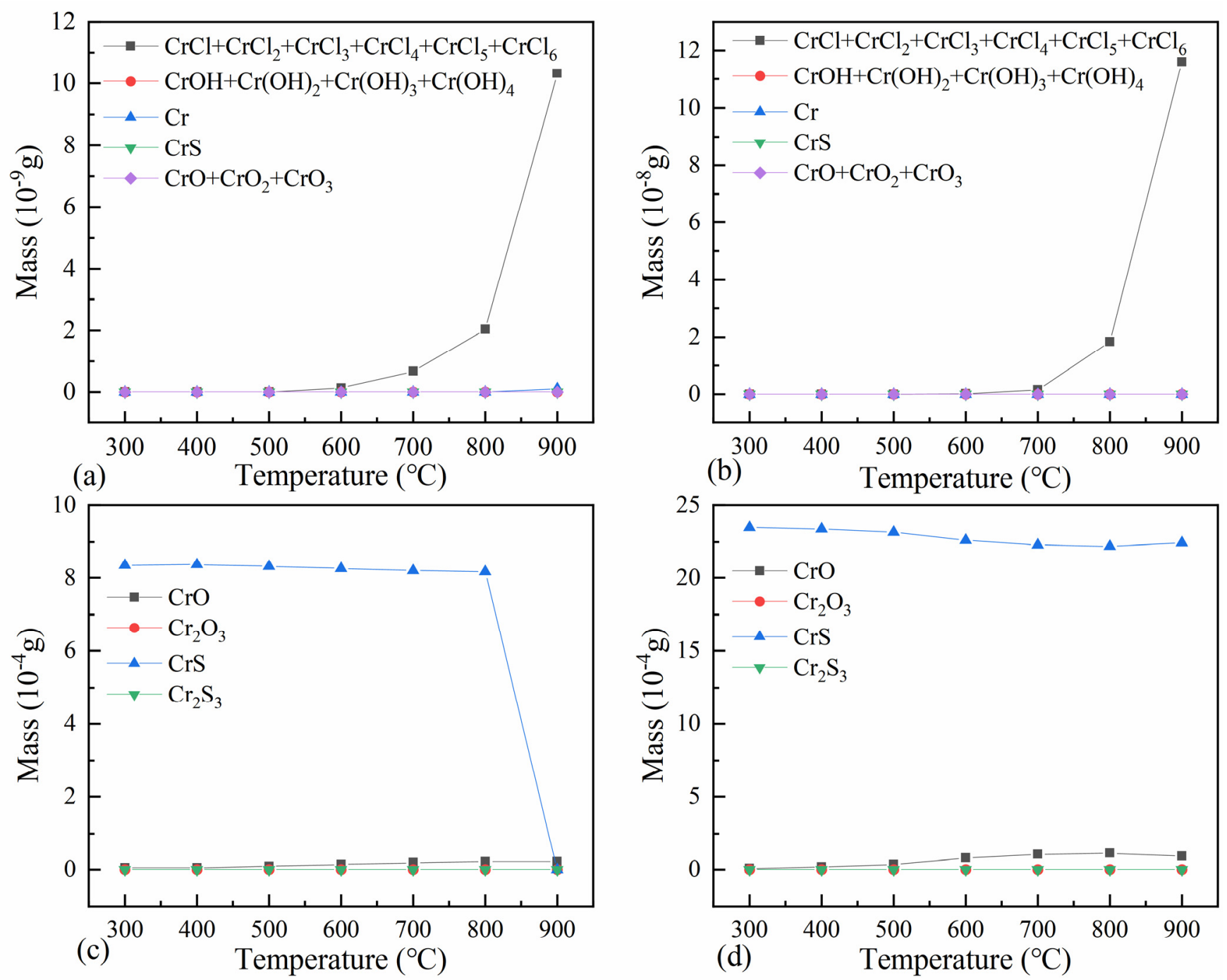

Figure 8. FactSage calculation results of $\mathrm{Cr}$ in $\mathrm{NMH}(\mathbf{a}, \mathbf{c})$ and $\mathrm{GL}(\mathbf{b}, \mathbf{d})$ coal.

\section{Conclusions}

The present study mainly focused on the modes of occurrence of $\mathrm{Cr}$ in two low-rank coals and their release and transfer behaviors in fixed-bed reactor pyrolysis. From the discussions, it could be concluded that:

(1) Sequential chemical extraction showed that the organic matter, aluminosilicate, carbonate (including monosulfide, sulfate, phosphate, and oxides) were the dominant modes of occurrence of $\mathrm{Cr}$, share of which were $32.9 \% / 35.7 \%, 34.8 \% / 26.4 \%$, and $29.8 \% / 34.3 \%$, separately, while $\mathrm{Cr}$ bounded to disulfide accounted for only a small part (about $3 \%$ ) in two low-rank coals. 
(2) Raw coal pyrolysis indicated that the release ratio of $\mathrm{Cr}$ increased with the rise of temperature. The release ratio of $\mathrm{Cr}$ in GL coal was higher than that in NMH coal in 400-800 ${ }^{\circ} \mathrm{C}$, which was mainly attributed to the high content of $\mathrm{Cr}$ bound to organic matter and less content of the mineral associated form of $\mathrm{Cr}$ in GL coal. A rapid increase in the $\mathrm{Cr}$ release ratio in GL coal at $600{ }^{\circ} \mathrm{C}$ was due to the decomposition of disulfide.

(3) Single-component samples pyrolysis demonstrated that $\mathrm{Cr}$ bounded to organic matter was almost completely released within $600{ }^{\circ} \mathrm{C}$. The release temperature range of $\mathrm{Cr}$ bounded to aluminosilicate and disulfide was shown to be $>600{ }^{\circ} \mathrm{C}$ and $400-600{ }^{\circ} \mathrm{C}$, respectively. At high pyrolysis temperature, $\mathrm{Cl}$ reacted with $\mathrm{Cr}$ bounded to minerals to form $\mathrm{Cr}$ chlorides with a lower boiling point, which enhanced the volatility of $\mathrm{Cr}$ and reduced the volatilization temperature of $\mathrm{Cr}$.

(4) FactSage thermochemical simulation suggested that gas products were chlorides, hydroxides, $\mathrm{Cr}, \mathrm{CrS}$, and oxides, among which chlorides were the dominant product. The solid products were mainly $\mathrm{CrO}, \mathrm{Cr}_{2} \mathrm{O}_{3}, \mathrm{CrS}$, and $\mathrm{Cr}_{2} \mathrm{~S}_{3}$, the content of which was much higher than that of gas products, showing their high thermal stability. The dominant form of $\mathrm{Cr}$ in chars were sulfides and oxides, which were closely related to the carbonate and aluminosilicate associated form of $\mathrm{Cr}$, as the main form of $\mathrm{Cr}$ in raw coals. The results of the equilibrium calculation were consistent with the experimental results.

Author Contributions: Conceptualization, L.Z. and S.Z.; methodology, X.W. and L.Z.; formal analysis, H.Z. and Y.M.; investigation, Y.L., C.J. and C.Z.; writing-original draft preparation, X.W. and L.Z.; writing—review and editing, L.Z. and G.Z.; visualization, L.B.; supervision, L.Z. and S.Z.; funding acquisition, L.Z. All authors have read and agreed to the published version of the manuscript.

Funding: This research was funded by the National Natural Science Foundation of China, grant number 51804313 and 52105232, Yue Qi Young Scholar Project, China University of Mining \&Technology, Beijing, grant number 2020QN10 and the Fundamental Research Funds for the Central Universities, grant number 2020YQHH08.

Institutional Review Board Statement: Not applicable.

Informed Consent Statement: Not applicable.

Data Availability Statement: All data used to support the findings of this study are included within the article.

Conflicts of Interest: The authors declare no conflict of interest.

\section{References}

1. Zhou, L.; Zhang, G.; Zhang, L.; Klinger, D.; Meyer, B. Effects of Contact Conditions between Particles and Volatiles during Co-Pyrolysis of Brown Coal and Wheat Straw in a Thermogravimetric Analyzer and Fixed-Bed Reactor. Processes $2019,7,179$. [CrossRef]

2. Yang, L.; Wang, Q.; Bai, X.; Deng, J.; Hu, Y. Mapping of Trace Elements in Coal and Ash Research Based on a Bibliometric Analysis Method Spanning 1971-2017. Minerals 2018, 8, 89. [CrossRef]

3. Vejahati, F.; Xu, Z.; Gupta, R. Trace elements in coal: Associations with coal and minerals and their behavior during coal utilization-A review. Fuel 2010, 89, 904-911. [CrossRef]

4. Baruthio, F. Toxic effects of chromium and its compounds. Biol. Trace Elem. Res. 1992, 32, 145-153. [CrossRef]

5. Dang, J.; Xie, Q.; Liang, D.; Wang, X.; Dong, H.; Cao, J. The Fate of Trace Elements in Yanshan Coal during Fast Pyrolysis. Minerals 2016, 6, 35. [CrossRef]

6. Zhang, H.; Zhao, S.; Niu, Q.; Chen, S.; Meng, X.; Zhang, D.; Li, M.; Liang, P. Mercury distribution in Guizhou bituminous coal and its releasing behavior during mild pyrolysis process. Fuel Process. Technol. 2019, 185, 38-45. [CrossRef]

7. Sotiropoulou, R.E.P.; Serafidou, M.; Skodras, G. Thermal mercury removal from coals: Effect of pyrolysis conditions and kinetic analysis. Fuel 2019, 238, 44-50. [CrossRef]

8. Guo, R.; Yang, J.; Liu, D.; Liu, Z. The fate of As, Pb, Cd, Cr and Mn in a coal during pyrolysis. J. Anal. Appl. Pyrolysis 2003, 70, 555-562. [CrossRef]

9. Guo, R.; Yang, J.; Liu, Z. Behavior of trace elements during pyrolysis of coal in a simulated drop-tube reactor. Fuel 2004, 83, 639-643. [CrossRef]

10. Guo, R.; Yang, J.; Liu, Z. Thermal and chemical stabilities of arsenic in three Chinese coals. Fuel Process. Technol. 2004, 85, 903-912. [CrossRef] 
11. Khare, P.; Baruah, B.P. Chemometric analysis of trace elements distribution in raw and thermally treated high sulphur coals. Fuel Process. Technol. 2010, 91, 1691-1701. [CrossRef]

12. Wei, X.; Zhang, G.; Cai, Y.; Li, L.; Li, H. The volatilization of trace elements during oxidative pyrolysis of a coal from an endemic arsenosis area in southwest Guizhou, China. J. Anal. Appl. Pyrolysis 2012, 98, 184-193. [CrossRef]

13. Wu, H.; Glarborg, P.; Frandsen, F.J.; Dam-Johansen, K.; Jensen, P.A.; Sander, B. Trace elements in co-combustion of solid recovered fuel and coal. Fuel Process. Technol. 2013, 105, 212-221. [CrossRef]

14. Querol, X.; Fernández-Turiel, J.; López-Soler, A. Trace elements in coal and their behaviour during combustion in a large power station. Fuel 1995, 74, 331-343. [CrossRef]

15. Frandsen, F.; Dam-Johansen, K.; Rasmussen, P. Trace elements from combustion and gasification of coal-An equilibrium approach. Prog. Energy Combust. Sci. 1994, 20, 115-138. [CrossRef]

16. Chen, C.; Luo, Z.; Yu, C. Release and transformation mechanisms of trace elements during biomass combustion. J. Hazard. Mater. 2019, 380, 120857. [CrossRef]

17. Miller, B.; Dugwell, D.R.; Kandiyoti, R. The Influence of Injected $\mathrm{HCl}$ and $\mathrm{SO}_{2}$ on the Behavior of Trace Elements during Wood-Bark Combustion. Energy Fuels 2003, 17, 1382-1391. [CrossRef]

18. Zhang, J.; Han, C.-L.; Xu, Y.-Q. The release of the hazardous elements from coal in the initial stage of combustion process. Fuel Process. Technol. 2003, 84, 121-133. [CrossRef]

19. Wang, J.; Yang, Z.; Qin, S.; Panchal, B.; Sun, Y.; Niu, H. Distribution characteristics and migration patterns of hazardous trace elements in coal combustion products of power plants. Fuel 2019, 258. [CrossRef]

20. Wang, T.; Yang, Q.; Wang, Y.; Wang, J.; Zhang, Y.; Pan, W.-P. Arsenic release and transformation in co-combustion of biomass and coal: Effect of mineral elements and volatile matter in biomass. Bioresour. Technol. 2020, 297, 122388. [CrossRef]

21. Kolker, A.; Huggins, F.E.; Palmer, C.A.; Shah, N.; Crowley, S.S.; Huffman, G.P.; Finkelman, R.B. Mode of occurrence of arsenic in four US coals. Fuel Process. Technol. 2000, 63, 167-178. [CrossRef]

22. Yang, N.; Tang, S.; Zhang, S.; Chen, Y. Modes of Occurrence and Abundance of Trace Elements in Pennsylvanian Coals from the Pingshuo Mine, Ningwu Coalfield, Shanxi Province, China. Minerals 2016, 6, 40. [CrossRef]

23. Rajabzadeh, M.A.; Ghorbani, Z.; Keshavarzi, B. Chemistry, mineralogy and distribution of selected trace-elements in the Parvadeh coals, Tabas, Iran. Fuel 2016, 174, 216-224. [CrossRef]

24. Luo, G.; Ma, J.; Han, J.; Yao, H.; Xu, M.; Zhang, C.; Chen, G.; Gupta, R.; Xu, Z. Hg occurrence in coal and its removal before coal utilization. Fuel 2013, 104, 70-76. [CrossRef]

25. Xiong, Y.; Xiao, T.; Liu, Y.; Zhu, J.; Ning, Z.; Xiao, Q. Occurrence and mobility of toxic elements in coals from endemic fluorosis areas in the Three Gorges Region, SW China. Ecotoxicol. Environ. Saf. 2017, 144, 1-10. [CrossRef] [PubMed]

26. Zhang, J.; Ren, D.; Zheng, C.; Zeng, R.; Chou, C.-L.; Liu, J. Trace element abundances in major minerals of Late Permian coals from southwestern Guizhou province, China. Int. J. Coal Geol. 2002, 53, 55-64. [CrossRef]

27. Luo, G.; Yao, H.; Xu, M.; Gupta, R.; Xu, Z. Identifying modes of occurrence of mercury in coal by temperature programmed pyrolysis. Proc. Combust. Inst. 2011, 33, 2763-2769. [CrossRef]

28. Guo, S.; Zhang, L.; Niu, X.; Gao, L.; Cao, Y.; Wei, X.-X.; Li, X. Mercury release characteristics during pyrolysis of eight bituminous coals. Fuel 2018, 222, 250-257. [CrossRef]

29. Guo, S.; Yang, J.; Liu, Z. Characterization of Hg in Coals by Temperature-Programmed Decomposition-Atomic Fluorescence Spectroscopy and Acid-Leaching Techniques. Energy Fuels 2012, 26, 3388-3392. [CrossRef]

30. Zhou, L.; Guo, H.; Chu, M.; Chang, Z.; Wang, X.; Zhang, G.; Gong, Y.; Qu, Y. Eeffects of occurrence mode of Cd in low rank coal on its volability during pyrolysis process. J. China Coal Soc. 2019, 44, 323-331. (In Chinese) [CrossRef]

31. Zhou, L.; Guo, H.; Wang, X.; Chu, M.; Zhang, G.; Zhang, L. Effect of occurrence mode of heavy metal elements in a low rank coal on volatility during pyrolysis. Int. J. Coal Sci. Technol. 2019, 6, 235-246. [CrossRef]

32. Zhou, C.-C.; Zhang, N.; Peng, C.; Cong, L.; Ouyang, C.; Han, R. Arsenic in Coal: Modes of Occurrence, Distribution in Different Fractions, and Partitioning Behavior during Coal Separation-A Case Study. Energy Fuels 2016, 30. [CrossRef]

33. Steel, K.M.; Besida, J.; O'Donnell, T.A.; Wood, D.G. Production of Ultra Clean Coal: Part I-Dissolution behaviour of mineral matter in black coal toward hydrochloric and hydrofluoric acids. Fuel Process. Technol. 2001, 70, 171-192. [CrossRef]

34. Steel, K.M.; Patrick, J.W. The production of ultra clean coal by chemical demineralisation. Fuel 2001, 80, 2019-2023. [CrossRef]

35. Riley, K.W.; French, D.H.; Farrell, O.P.; Wood, R.A.; Huggins, F.E. Modes of occurrence of trace and minor elements in some Australian coals. Int. J. Coal Geol. 2012, 94, 214-224. [CrossRef]

36. Wenfeng, W.; Yong, Q.I.N.; Bo, J.; Xuehai, F.U. Modes of Occurrence and Cleaning Potential of Trace Elements in Coals from the Northern Ordos Basin and Shanxi Province, China. Acta Geol. Sin.-Engl. Ed. 2010, 78, 960-969. [CrossRef]

37. Wang, J.; Sharma, A.; Tomita, A. Determination of the Modes of Occurrence of Trace Elements in Coal by Leaching Coal and Coal Ashes. Energy Fuels 2003, 17, 29-37. [CrossRef]

38. Liu, J.; Yang, Z.; Yan, X.; Ji, D.; Yang, Y.; Hu, L. Modes of occurrence of highly-elevated trace elements in superhigh-organic-sulfur coals. Fuel 2015, 156, 190-197. [CrossRef]

39. Zhang, G. Mineral Matter Behavior during Co-Gasification of Coal and Biomass. Ph.D. Thesis, Technische Universität Bergakademie Freiberg, Freiberg, Germany, 2014. Available online: https:/ /nbn-resolving.org/urn:nbn:de:bsz:105-qucosa-154413 (accessed on 2 November 2021). 